\title{
The Influence of Regional Social Inequality and Labour Market Characteristics on Health
}

\author{
Christiane Gross, Peter Kriwy
}

\begin{abstract}
The influence of contextual factors on individual health status has been demonstrated by a number of studies even when controlling for the individual socio-economic situation (and other relevant factors). The article examines whether and to what extent variables of the place of residence have an effect on individual health status. We do not only refer to income levels and inequality, but also to effects of the educational level and inequality and the regional unemployment rate. As data basis for the individual level, we use the 2006 wave of the German SocioEconomic Panel Study (SOEP) and add regional information on the aggregate level based on the regional units (Raumordnungsregionen) of the Microcensus of 2005. These data will be analysed using multilevel models. The results reveal that regional educational inequality intensifies the individual educational effect, whereby members of less-educated groups in educationally disparate regions exhibit particularly low health chances. In addition, a high regional unemployment rate intensifies the negative effect of individual unemployment on men's health.
\end{abstract}

Keywords: Health · Regional inequality · Education · Labour market · Context effect

\section{Introduction}

The article examines whether and to what extent health inequality in Germany can be explained by regional variables (contextual effects) when controlling for individual effects (compositional effects). Two different types of regional contexts are taken into consideration: variations in average levels (with regard to household income, educational level and unemployment) and variations in inequality (income inequality and educational inequality). In addition, we analyse whether the influences of individual variables vary depending on the regional context.

Previous analyses conducted to explain regional health inequalities in Germany are mostly limited to single cities and their districts as territorial units. We use representative data for Germany as a whole and - unlike most international studies 
- we take regional differences in levels as well as inequality variables on individual health into account. The current research and theoretical sections consequently refer to studies with very different territorial units (from neighbourhoods to national states), while our analyses are based on regional units (Raumordnungsregionen) in Germany, which are in between in terms of size.

The fact that people in poorer neighbourhoods are on average less healthy has been known since 1828 from the historic works of Villermé (Krieger 2001) and has in many cases been proven for all kinds of different regions (Haan et al. 1987; Ecob/ Smith 1999; Bosma et al. 2001; Borrell et al. 2004). This finding is not surprising given that poorer quarters are inhabited by poorer people who are at a health disadvantage due to a variety of social mechanisms. This explains the correlation between the poverty of a region and the average mortality and morbidity of its inhabitants by the composition of the population in terms of age, gender, marital status and socio-economic status (compositional effects). Which mechanisms play a role here will be clarified in Section 2.1 as part of the theoretical explanatory approaches (Section 2). The composition of the population, however, could not adequately explain the mortality and morbidity rates; therefore influences of the regional environment were taken into account (contextual effects). While the positive effect of a region's prosperity on the health of its inhabitants is relatively easy to understand (less pollution, financial means for health care, etc.), explaining the negative effect of social inequality on health chances is certainly more difficult. Section 2.2 therefore describes in great detail the contextual effects of income level and inequality as well as educational level and inequality and the regional unemployment rate on individual health chances and explains which social mechanisms might be responsible for these. The contextual effects should also persist when we control for individual socio-economic situations. The hypotheses derived from the preceding sections are tested with the 2006 SOEP and 2005 Microcensus using competing multilevel models (cf. Section 3) and their results will be presented afterwards (Section 4). The article closes with a summary (Section 5).

\section{Theoretical approaches}

\subsection{Individual determinants on health status}

The position of a person along the dimensions of social differentiation does not have a direct effect on morbidity and mortality, but rather via intermediary variables (health behaviour, resources and distress) (Rothman 1986: 89-90).

Figure 1 shows an overview of the postulated correlations, which will be described in greater detail in the following. The centre column contains the social mechanisms intended to explain morbidity and mortality based on social differentiation.

We can assume that there is empirically well-founded proof that health behaviour such as tobacco and alcohol consumption, physical activity, eating habits or healthcare utilisation affect health (see Helmert/Schorb 2009 for a summary). The 
Fig. 1: Explanatory model of socially differentiated health chances

\section{Social differentiation}

Mediators

Health

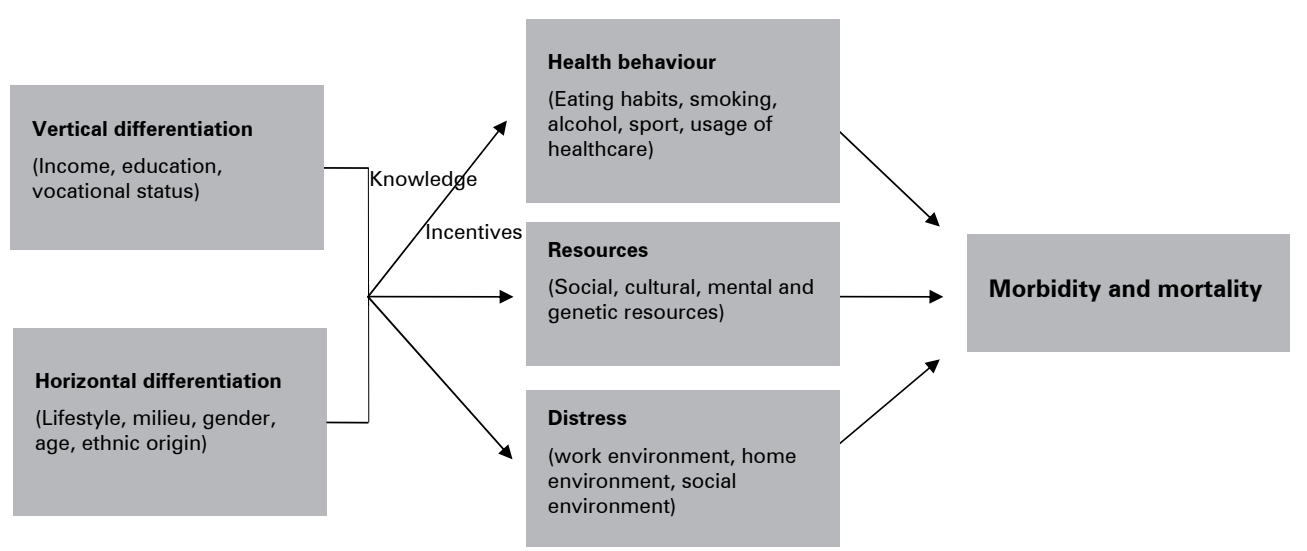

Source: Based on Jungbauer-Gans/Gross (2009: 91)

different dimensions of health behaviour are influenced by factors of social differentiation, which are explained in examples in the following. For example, an individual's eating habits (Gerhards/Rössel 2003; Helmert 2003; Prahl/Setzwein 1999) as well as smoking prevalence (Helmert 2003; Lampert/Thamm 2004, 2007; Statistisches Bundesamt 1998), alcohol consumption (Helmert et al. 1997; Mielck 2000), extent of physical activity (Helmert et al. 1997; Zubrägel/Settertobulte 2003) and healthcare utilisation (Altenhofen 1998; Janßen et al. 2009; critique: Mielck 2000) vary depending on social class. Usually income, education and vocational position (as the three main dimensions of prevalent class concepts) have independent effects on health behaviour (as an example for smoking prevalence cf. Gross and Groß 2008). Similarly, variables of horizontal differentiation such as age, gender and ethnic origin determine health behaviour. For instance, smoking behaviour (Gross/ Groß 2008) and alcohol consumption (Richter/Settertobulte 2003) differ according to gender and age. Likewise healthcare utilisation is gender-specific (summarised by Rieker/Bird 2000). Additionally, health behaviour (e.g. drug use and type of physical activity) is closely linked to lifestyle and social milieu.

Referring to resources and distress the imbalance of effort and reward is considered particularly damaging to health (Siegrist 1996; Rugulies/Siegrist 2002; Siegrist et al. 2004; Siegrist/Theorell 2006; Peter 2009). Steinkamp (1993) emphasises that the objective effort-reward ratio is not nearly as important as its subjective assessment. Social resources or social capital can either have a direct positive effect on health (Holt-Lunstad et al. 2010) or buffer the negative effect of distress on health (e.g. Nuckolls et al. 1972). Complex measurements of social integration show a greater influence on mortality risk than simple measurements of social capital such as cohabitation or marital status (Holt-Lunstad et al. 2010). Genetic resources or biological factors produce gender-specific prevalence rates for example of cardiac dis- 
eases (Lane/Cibula 2001). Both physical and mental stress factors are more frequent among people with low socio-economic status (SES) and are therefore well suited for explaining the correlation between SES and health chances (Greiner 2001: 150). The decisive aspect here is the feeling of leading a self-determined life and possessing social confidence (Link/Phelan 2000; Mirowsky et al. 2000).

Current research on the influence of individual variables on health can only be mentioned briefly here and are not discussed in detail (for more detail cf. Jungbauer-Gans/Gross 2009). Nonetheless, this section was intended to sensitise the reader to the main individual factors that need to be controlled for in order to study the influence of social context on subjective health.

We must additionally note here that separating compositional and contextual effects is not seen without disapproval (e.g. Cummins et al. 2007). The theoretical reasons are summarised by Macintyre et al. (2002) as follows: (a) The characteristics of individuals and households may be influenced by local environment, (b) the individual control variables are possibly intervening rather than confounded variables and (c) there is a lack of extensive theoretical explanations describing the mechanisms between local environment and health behaviour or health. Gravelle (1998) provides a statistical critique of the analytical separation of compositional and contextual effects.

\subsection{Contextual effects of the social environment on individual health status}

The difficulty of determining causal mechanisms regarding the influence of social contextual characteristics on health is mainly due to the fact that the size of the social context varies greatly. While some studies make international comparisons using the national state as territorial unit (e.g. Wilkinson/Pickett 2010), other studies literally examine neighbourhood effects at the city district level (e.g. Wolf 2004). In spite of these differences, the theoretical explanatory approaches differ astonishingly little. For instance, both at the national and at the district level, it is possible to suppose a health-promoting effect of social capital, although operationalising social capital for these two dimensions may be quite different. ${ }^{1}$ Similarly, social deprivation can refer to very different territorial units. The determinants used (income and educational level and disparities as well as the unemployment rate) and the underlying social mechanisms (e.g. relative deprivation, social capital) can be applied to different territorial units.

The majority of studies examining the correlation between health indicators and characteristics of the region discover - even controlled for the composition of inhabitants - significant contextual effects of the places of residence (summarised by Robert/House 2001). In the following, we will discuss these influential factors in

1 In internationally comparative studies, social capital is often measured via social trust or membership in associations, while the influence of social capital in neighbourhoods can be operationalised quite tangibly using neighbourly support. 
terms of differences in levels with regard to income, education and unemployment (Section 2.2.1) as well as inequality variables with regard to income and education (Section 2.2.2). In doing so, we will present results of studies that make use of very different territorial units.

\subsubsection{Average level of income and education, and unemployment rates}

Numerous studies have shown significantly higher mortality rates in non-privileged places of residence controlled for individual factors (Yen/Kaplan 1999b; Bosma et al. 2001; Martikainen et al. 2003; Borrell et al. 2004; Marinacci et al. 2004) and only a few have found none (Sloggett/Joshi 1994; Veugelers et al. 2001; Gerdtham/ Johannesson 2004). Similarly, controlled for individual risk factors, an increased occurrence of depression symptoms (Yen/Kaplan 1999a) and cardiovascular diseases (Diez-Roux 2001; Marinacci et al. 2004) were ascertained in non-privileged neighbourhoods. The rate of miscarriages and chronic diseases such as coronary heart disease is even high in deprived neighbourhoods when controlling for individual education, employment and income (Pickett/Pearl 2001).

The differing effects of the average wealth and income levels on health chances in an international comparison is explained with the different characteristics of welfare state tendencies, which can mitigate both income inequality and its impacts. According to van Lenthe (2006), welfare and public assistance can cushion the negative effects of a poorer residential area on health. Dahl et al. (2006), however, do not find a systematic correlation between egalitarian/welfare state versus liberal/ conservative tendencies and health inequality. According to Stafford and Marmot (2003) poorer people particularly suffer under a non-privileged neighbourhood, which they explain with greater dependency on local resources.

The average educational level in neighbourhoods as an independent effect on the probability for older men to be treated for heart ailments was studied in Sweden. Low educational levels in the neighbourhood increase the probability of being treated for heart problems as an outpatient or inpatient (Larsen/Merlo 2005).

High unemployment in a residential area can act as an indicator for low political and economic participation and empowerment, regardless of the poverty or unemployment of individuals (O'Campo et al. 1997). Using a sample of the Amsterdam residential population, Reijneveld et al. (2000) show that, controlled for individual variables and compared to a district with low unemployment, ${ }^{2}$ life in a district with high unemployment leads to a significantly higher risk of poorly selfassessed health status, physical complaints, physical long-term restrictions, obesity and regular cigarette use. The results concerning the place-of-residence effect of high unemployment on a high mortality risk are, however, contradicttory. Using data from the Dutch GLOBE study, Bosma et al. (2001) show evidence of this effect and similarly Stafford et al. (2004) prove the unhealthy effect of high unemploy-

2 The residential areas were classified using the 33 percent and 66 percent quantile in three equal-sized categories with low, medium and high unemployment rates. 
ment with data from the Whitehall II study (London and Helsinki), whereby they only control for age and gender at level I. These are contradicted by analyses with data from a Canadian survey by Veugelers et al. (2001), who cannot ascertain significant effects of unemployment (as well as the average wealth and educational level) in a neighbourhood on mortality risk. Also, a high unemployment rate in residential districts reduces the protective effect of prenatal check-ups on the risk of low birth weight (O'Campo et al. 1997). Van Lenthe et al. (2005a), who use data sources from six different studies (ARIC, GLOBE, Whitehall II, Helsinki, Turin and Madrid) and calculate separate models for men and women, also reach contradictory results with regard to the effect of the unemployment rate on individual mortality. Without controlling for individual education and employment, all six models for men exhibit a significantly negative effect of unemployment, which disappears, however, in two models when they are controlled for these individual socio-economic factors. The unemployment rate is significant in three of the five models for women (the Helsinki data contain only male subjects), regardless of whether controlled for education and employment (van Lenthe et al. 2005a).

There are two possible mechanisms that might explain to what extent high unemployment in a residential region impacts the health-detrimental effect of individual unemployment. The negative future prospects of the unemployed in a structurally weak region may either have particularly health damaging effects or the stigmatising effect of unemployment in a region where many people share the same fate may be weaker and therefore less detrimental to health.

There are also two mechanisms that might explain the correlation between prosperity of residential districts and health: selective migration and actual causation. According to selective migration ill people tend to move to neighbourhoods with a low status while healthy people tend to move to residential areas with a higher status - both controlled for individual SES. However, it is possible that the social origin accounts for both the choice of living area as well as health (van Lenthe 2006). Monden et al. (2006) find evidence for the correlation between the SES of the childhood neighbourhood and the neighbourhood where one spends adult life. Both the early and later neighbourhood in the life of a person - even when controlled for individual SES - correlates with smoking behaviour and obesity, however not with excessive alcohol consumption (Monden et al. 2006). According to van Lenthe et al. (2007), "upward migration" seems easier for women and highly educated people than for men and people with a lower educational background. All in all, van Lenthe et al. (2007) assume a barely noticeable influence of selective migration to explain place-of-residence differences in health.

Causation applies when actual characteristics of the places of residence (living quality, low noise pollution, leisure and sport possibilities, environmental factors, etc.) act as mediators on health. According to the analyses by Wolf (2004), the social status of the urban district and the quality of the outdoor air are decisive for individual health. Voigtländer et al. (2011) specify the influence of outdoor air to the effect that only the subjectively perceived quality of the outdoor air effects physical health, not the objectively measured air quality. Kamphuis et al. (2007) provide evidence, for instance, that people with low SES perceive the characteristics of 
their neighbourhood (e.g. safety issues, lack of recreational opportunities) more as barriers to physical activities than people with high SES. According to Kemptner et al. (2008), people in so-called risk neighbourhoods do less sport and are more frequently overweight. Lee et al. (2007) show more frequent tiring activities among women with a lower SES, but less athletic activities than women with high SES. Similarly, people in non-privileged neighbourhoods frequently cycle to work or shopping, but use a bicycle less often for sport. Generally speaking, living in nonprivileged neighbourhoods is accompanied by lesser physical activity even when controlling for individual variables (van Lenthe et al. 2005b).

One often-neglected aspect of the influence of residential-area characteristics is the contagiousness of diseases as well as of health behaviour. In an area with a very high percentage of smokers it is presumably harder to quit smoking and easier to begin than in an area with a low percentage of smokers (van Lenthe 2006).

We therefore assume that the chances for very good or good health increase in regions with a high regional average income (Hypothesis 1a), a high regional educational level (Hypothesis 2a) as well as a low unemployment rate (Hypothesis 3a). In addition, a high regional average income should lessen the individual income effect on health (Hypothesis $1 b$ ), a high regional educational level should reduce the individual educational effect on health (Hypothesis $2 b$ ) and high regional unemployment should strengthen the negative effect of individual unemployment on health (Hypothesis 3b).

\subsubsection{Income inequality and educational inequality}

Numerous studies provide evidence for the correlation between income inequality and health indicators (among them Cubbin et al. 2000; Babones 2008). However, to interpret the compositional versus contextual effect it is decisive whether this correlation remains when controlling for individual factors. Beckfield (2004) ascertains a reduction in the significant effect of income inequality when individual factors are taken into account, while the income inequality effect disappears entirely when fixed-effects models are used to control for unobserved heterogeneity. Backlund et al. (2007) verify that the correlation between income inequality and mortality is only valid for people under the age of 65 . Babones (2008) states that the causality between income inequality and health is difficult to prove since income inequality hardly varies over time. McLeod et al. (2004) provide evidence for an insignificant inequality effect controlled for the ethnic composition of the population at the national level. A few studies find no indications that income inequality affects individual health indicators (e.g. Mellor/Milyo 2002). Cubbin et al. (2000) note that the correlation between income inequality and self-reported morbidity is not robust if the operationalisation of income inequality and health indicators vary. Voigtländer et al. (2010) conducted a study on the influence of regional deprivation on individual health using SOEP data. Although they possess information for example on regional unemployment and employment rates, density of physicians and income levels, they only report the regional effect of an east-west dummy in the multilevel analyses. 
According to Wilkinson (2001: 1), the frequently documented finding that the life expectancy of people rises when income equality in their country increases has largely remained unexplained. Wilkinson (2001: Chapter 6) reveals that egalitarian societies are more healthy and exhibit greater social cohesion. The unhealthy effects of relative poverty do not consist of, say, poorer living conditions, increased cigarette use and poorer nutrition, but from a subjective feeling of relative deprivation:

"To feel depressed, cheated, bitter, desperate, vulnerable, frightened, angry, worried about debts or job and housing insecurity; to feel devalued, useless, helpless, uncared for, hopeless, isolated, anxious and like a failure: these feelings can dominate people's whole experience of life, colouring their experience of everything else. It is the chronic stress arising from feelings like these which does the damage." (Wilkinson 2001: 262, translated by CPoS)

In addition to Wilkinson's explanation of relative deprivation, Gravelle (1998) notes an individual income interpretation and Lynch et al. (2000) a neo-material interpretation. Gravelle (1998) warns against analysing the correlation between social inequality and disease with aggregate data because one could otherwise draw an ecological fallacy. Therefore, the much discussed work The Spirit Leve/ by Wilkinson and Pickett (2010), which is only based on aggregate data and also does not examine and adhere to basal model assumptions, must be interpreted with great caution. Lynch et al. (2000) explain the neo-material interpretation using a metaphor of first and second-class airline passengers. While according to a psychosocial explanation of relative deprivation second-class passengers feel bad because they observe the comfort of first class when walking through the plane, feel disadvantaged and thus develop negative emotions, according to the neo-material explanation, it is the poorer seats and poorer food in second class that lead to a poorer assessment of health after the flight.

Subramanian and Kawachi (2004) argue that the average health of the population would improve with a lessening of income inequality since the health of the poorer part of the population would profit greatly from an individual income growth, while the rich part of the population would have hardly measurable losses as a result of decreased individual income.

Another explanation focuses on social capital. According to this approach, a high degree of income inequality leads to low social capital in a living area, which in turn is made responsible for health burdens (Mielck 2008). The study by Kawachi et al. (1997) did the pioneering work to prove this chain of causation. The study operationalised social capital through social involvement in clubs and organisations and through social trust. Similarly, Lochner et al. (2003) confirm the correlation between social trust, reciprocity and social participation on the one hand and higher life expectancy on the other controlled for material deprivation. According to Engström et al. (2008) the risk factors of low self-assessed health are rather indicated by social participation and social trust (horizontal contextual social capital) than by political trust and political participation (vertical contextual social capital). Social capital correlates negatively with an index of neighbourhood problems according to Steptoe and Feldman (2001). 
Educational inequality and individual health chances are also highly correlated. Regional educational inequality was examined in 59 New York neighbourhoods as a predictor of various health indicators. According to this study, highly educated people in the neighbourhood have a health-promoting effect on all people in the affected areas (Galea/Ahern 2005).

Based on the influence of regional inequality variables on individual health, we assume high income equality (Hypothesis $4 a$ ) and high educational inequality ( $\mathrm{Hy}$ pothesis 5 a) to have a health-promoting effect. In addition, high regional income inequality should increase the individual income effect (Hypothesis $4 \mathrm{~b}$ ) and also high educational inequality should increase the individual educational effect $(\mathrm{Hy}$ pothesis $5 b$ ). Table 1 provides an overview of all our hypotheses.

Tab. 1: Overview of hypotheses

Main effects of social context: Individual health improves with ...

... high regional average income

(Hypothesis 1a).

... high regional educational level

(Hypothesis 2a).

... low regional unemployment rate in a region

(Hypothesis 3a).

... high regional income equality

(Hypothesis 4a).

... high regional educational inequality

(Hypothesis 5a).

Interaction effects between social context and individual variables:

A high regional average income lessens the effect of

(Hypothesis 1b). individual income on health.

A high regional educational level reduced the effect of

(Hypothesis 2b). individual education on health.

High regional unemployment intensifies the negative effect of individual unemployment on health.

High regional income inequality intensifies the effect of individual income on health.

High educational inequality intensifies the effect of individual education on health.

(Hypothesis 3b).

(Hypothesis 4b).

(Hypothesis 5b).

Source: own design

\section{Data and methods}

Previous studies usually made use of territorial units formed for administrative purposes (Tampubolon 2012). Territorial units defined in this manner do not, however, necessarily conform to the subjectively assessed or perceived neighbourhood. Hence, if we use administrative districts, the contextual effects of the residential districts are underestimated, corresponding to a conservative estimation model (van Lenthe 2006). Health studies that employ contextual effects as explanatory variables usually use the direct neighbourhood (Wilkinson 1997) or entire nations (Wilkinson and Pickett 2010) as reference group. It is basically possible to operation- 
alise the selected districts on a small scale with data from the Microcensus. ${ }^{3}$ Unfortunately, the Microcensus programme does not provide any useable variable to measure health. For this reason we did not use such extremely small-area selected districts for this study and chose the more irregular territorial unit of Raumordnungsregionen, which is compatible with data from the SOEP. This means we used the smallest possible territorial unit in Germany for which both the desired contextual characteristics are available and combination with useable health indicators at the individual level is possible.

Raumordnungsregionen (abbreviated below as RORs) are administered by the Federal Institute for Research on Building, Urban Affairs and Spatial Development in Bonn and largely correspond to the regional units of the federal states (Länder). They "form the spatial frame of reference for large-area analyses of the spatial/ structural starting position, large-area analyses of spatially effective federal funds, predictions of large-area development tendencies, statement on large-area disparities in the infrastructure and employment structure" (Bundesinstitut für Bau-, Stadtund Raumforschung im Bundesamt für Bauwesen und Raumordnung (BBR) 2009; translated by CPoS). The RORs are meant to correspond to functional spaces and, for example, cover the commuter linkage of employed people (BBR 2009). RORs are formed so that a large part of commuter movements take place within an ROR. An ROR is not merely an administrative unit, but also an experienced space. In addition, regions that are defined by means of commuter linkages are the relevant units for studying the effect of regional unemployment on individual employment chances or individual well-being and health. The number of RORs per state is roughly aligned to the size of the state; for instance Bavaria is divided up into 18 and SchleswigHolstein into 5 such regions. On average, approximately 852,000 people live in one ROR (authors' calculation based on information from the $B B R$ 2009). Since the composition of the RORs are neither comparable to urban districts, as used in small-area analyses, nor to entire national states, as used in internationally comparative studies, the extent to which previous results can be transferred to our study remains unclear. The descriptive distribution of the variables according to the 97 RORs is portrayed in Table $2 .^{4}$

The average monthly net household income in private households in the RORs in the year 2005 was almost $€ 2,500$. The minimum was $€ 1,856$ (eastern West Pomerania); the maximum of $€ 3,178$ was made in Munich and surroundings. The Gini coefficient for income inequality across all RORs is slightly under 34 . The minimum of 29 is exhibited by Mittweida in southeastern Saxony. The maximum income inequality is in Munich. The average years of education are approx. 12. The region with

3 Schunck and Windzio (2009) presented a convincing work on the self-employment of immigrants that uses multi-level analyses based on such selected districts.

4 An average of 7,027 observations in the 2005 Microcensus are available per ROR, whereby only the information from the heads of households are used to ascertain household income. These results were generated via the controlled remote data processing conducted by the Research Data Centre of the Federal Statistical Office. In this way, we had access to the complete number of cases of almost 700,000 individuals in the 2005 Microcensus. 
Tab. 2: Descriptive distribution of the context variables based on the 97 RORs (Level 2)

\begin{tabular}{lcrrrr}
\hline & $\begin{array}{c}\text { Case } \\
\text { numbers }\end{array}$ & Mean & $\begin{array}{l}\text { Standard } \\
\text { deviation }\end{array}$ & Minimum Maximum \\
\hline Avg. net household income in $€$ & 97 & 2466.16 & 304.81 & 1855.71 & 3178.18 \\
Income inequality (Gini) & 97 & 33.97 & 1.86 & 29.00 & 38.50 \\
Avg. years of education & 97 & 12.27 & 0.34 & 11.58 & 13.15 \\
Educational inequality (Gini) & 97 & 11.06 & 0.97 & 8.79 & 12.72 \\
Unemployment rate & 97 & 13.72 & 6.45 & 5.38 & 31.72 \\
\hline
\end{tabular}

Source: 2005 Microcensus, authors' calculations

the lowest level of education in Germany is Bremerhaven/Cuxhaven; the citizens with the highest level of education in Germany live in Dresden, closely followed by Munich. Unemployed people were those who cited that they were registered at the Federal Employment Office as unemployed or seeking work during the 2005 Microcensus survey. The unemployment rate reported here corresponds to the percentage of unemployed among people of working age at their main place of residence using the individual weighting factor. The lowest unemployment is recorded in the very south of Germany (including Oberallgäu, Kempten, Bad Tölz) while high unemployment is observed in the northeast (including Neubrandenburg, eastern and northern West Pomerania). The suitability of the relatively large RORs as structural units for the contextual level of the multilevel analyses was also checked for by analysing whether these are homogeneous territorial units. For this, bivariate analyses of variance were calculated with the dependent variables namely years of education as well as income and the independent variable namely the ROR. RORs explain 4 percent of the total variance for education (t-value 6.92) and 3 percent of the total variance for income (t-value 3.51). ${ }^{5}$ Although the percentage of variance explained with the RORs, and therefore the homogeneity of the units, is relatively low it becomes evident that the RORs are relevant analysis units for the variables used.

The Gini coefficient (Gini 1921; Pyatt 1976; Allison 1978) was also used to calculate educational inequality, for which the information on school leaving certificates, education and university studies were converted to years of education, which vary at the individual level between 8 and 18 years. For a better comparability, this coefficient was used both to measure income and educational inequality; it must be noted here that educational level and educational inequality may be highly correlated (Moore et al. 2007). In our data that is, however, not the case (Pearson correlation coefficient $=0.008, p>0.05$ ), but there is a strong statistical correlation (Pearson correlation coefficient $=0.684, p<0.001$ ) between income level and income ine-

5 The random-intercept-only model with the dependent variable of subjective health also confirms this result (see Section 4). 
quality. For this reason the results are reported both with and without level variables (average household income, average years of education).

The degree of urbanisation was controlled at the individual level. The dummy variables for small town $(20,000-100,000$ inhabitants) and city $(100,000$ inhabitants and more) do not, however, have an effect on individual health and are not listed in Tables 4 and 5.

The small-area information from the Microcensus based on the 97 RORs is from the year 2005. The individual data on health and relevant determining factors were supplied by the 2006 wave of the SOEP. This staggered data ensures that influences of regional inequality precede the individual effects.

Since the focus of this study is not on the individual level but the contextual level, we will only briefly present the SOEP variables. The dependent variable is self-rated health measured on a five-point scale and dichotomised for this article. The first two categories ("very good" and "good" health) were combined. Some research papers confirm the high (point biserial) correlation between subjective and objective health (/dler/Benyamini 1997; Heidrich et al. 2002; Case/Paxson 2005; Kriwy/Mie/ck 2006; Lyyra et al. 2009), meaning we can attribute a high criterion validity to self-rated health. In addition, subjective health is especially suitable for cross-sectional analyses, as the meta-analysis by Kondo et al. (2009) demonstrates. The age spectrum for these calculations was limited to 25 to 65 years. One reason for this is that older people in a panel in particular are subject to the survivor effect and it is therefore assumed that the "healthy old people" tend to take part in a panel more frequently, which impacts, for example, the estimation of life expectancy (Schnell/Trappmann 2006). Also income effects are considered effects of the individual net income, which suggests that people over the age of 65 years should be excluded from the calculations. Young people (under 25 years) were also excluded form the analyses since they do not yet exhibit any noticeable variations in their health status. Table 3 shows the distribution of the individual variables.

Since the spatial clustering impairs the independence of the elements, we used multilevel analysis (for an introductory overview cf. Hox 2002). The calculations are random effects logit models (random intercept and random slopes), which, unlike fixed effects models, take varying slopes across the regional units into consideration. ${ }^{6}$ The multilevel analyses were conducted using HLM6. Population-average estimations react less sensitively to erroneous specifications and distribution assumptions than unit-specific estimations. Since regionally varying variables are incorporated at the second analysis level and we are interested in average effects resulting from this in the population, use of population-average models is sufficient here (Neuhaus et al. 1991).

6 Fixed and corresponding random effects models were first tested competitively with the Hausman Test using Stata 11. The coefficients differ significantly from one another, if only to a minor extent. The test therefore narrowly turned out in favour of the random effects models. 
Tab. 3: Descriptive distribution of the individual variables (Level 1)

\begin{tabular}{|c|c|c|c|c|c|}
\hline & $\begin{array}{c}\text { Case } \\
\text { numbers }\end{array}$ & Mean & $\begin{array}{l}\text { Standard } \\
\text { deviation }\end{array}$ & Minimum & Maximum \\
\hline $\begin{array}{l}\text { Dependent variable: self-rated health } \\
(1=\text { very good/good })\end{array}$ & 15,529 & 0.53 & 0.50 & 0 & 1 \\
\hline \multicolumn{6}{|l|}{ Vertical differentiation: } \\
\hline Net income in $€$ & 10,229 & 1699.45 & 1310.60 & 35 & 30000 \\
\hline Net income in $€(\ln )^{a}$ & 15,550 & 4.96 & 3.14 & 0.69 & 10.31 \\
\hline Unemployed & 15,550 & 0.25 & 0.43 & 0 & 1 \\
\hline Control variable: homemaker & 15,550 & 0.11 & 0.31 & 0 & 1 \\
\hline Years of education & 15,227 & 13.18 & 2.67 & 8 & 18 \\
\hline \multicolumn{6}{|l|}{ Horizontal differentiation: } \\
\hline Age in years & 15,550 & 45.48 & 11.09 & 25 & 65 \\
\hline Gender ( $1=$ female $)$ & 15,550 & 0.52 & 0.50 & 0 & 1 \\
\hline Nationality ( $1=$ German) & 15,550 & 0.92 & 0.26 & 0 & 1 \\
\hline \multicolumn{6}{|l|}{ Health behaviour: } \\
\hline Regular tobacco consumption & 15,535 & 0.32 & 0.47 & 0 & 1 \\
\hline Regular alcohol consumption & 15,550 & 0.17 & 0.38 & 0 & 1 \\
\hline Body-mass index (metric) & 15,406 & 25.87 & 4.59 & 12.03 & 76.21 \\
\hline \multicolumn{6}{|l|}{ Resources: } \\
\hline Marital status $(1=$ married $)$ & 15,550 & 0.67 & 0.47 & 0 & 1 \\
\hline Has a confidant & 15,550 & 0.91 & 0.28 & 0 & 1 \\
\hline Square metres per person (In) & 15,505 & 3.67 & 0.47 & 1.39 & 6.04 \\
\hline \multicolumn{6}{|l|}{ Stress: } \\
\hline Job at risk & 15,550 & 0.13 & 0.34 & 0 & 1 \\
\hline More than 5 overtime hours & 15,550 & 0.19 & 0.39 & 0 & 1 \\
\hline Dissatisfied: dwelling & 15,550 & 0.13 & 0.34 & 0 & 1 \\
\hline Dissatisfied: family & 15,550 & 0.15 & 0.36 & 0 & 1 \\
\hline
\end{tabular}

a In order to be able to report the influence of unemployment of people, missing income data due to a lack of employment (not due to item nonresponse) was set at close to zero (2 euros monthly income). This makes even these income data logarithm-compatible and the resulting errors are controlled for by the variables homemaker and the unemployment dummy.

Note: Unless noted otherwise 1 means yes and 0 stands for no.

Source: SOEP 2006, authors' calculations

\section{$4 \quad$ Results}

The random-intercept-only model (not contained in Table 4) shows that the average health according to ROR varies in a highly significant way (t-value 3.76). The models in Table 4 provide information about the results at the individual level (level 1) and contextual level (level 2). At the individual level the results are mainly as expected and are only briefly outlined here since the main interest of this article is in regional effects. Better health chances are associated with higher education and higher income. With increasing age, health chances lessen and higher body-mass index and regular tobacco consumption are also accompanied by lesser prospects for good 
Tab. 4: Random effects logit models (dependent variable: self-rated health: $1=$ very good/good, age 25-65 years, population average models, robust standard errors)

\begin{tabular}{|c|c|c|c|}
\hline \multirow{2}{*}{ Level 1 Hndividua levell. } & \multicolumn{3}{|c|}{ Coefficient (t-value) } \\
\hline & Model A & Model B & Model C \\
\hline & & & \\
\hline Constant & $0.12(4.66)^{* * *}$ & $0.12(4.47)^{* * *}$ & $0.12(4.57)^{* * *}$ \\
\hline \multicolumn{4}{|l|}{ Vertical differentiation: } \\
\hline Net income in $€($ In) & $0.02(2.18)^{*}$ & $0.02(2.21)^{*}$ & $0.02(2.31)^{*}$ \\
\hline Unemployed & $-0.23(-3.45)^{* *}$ & $-0.23(-3.53)^{* *}$ & $-0.23(-3.48)^{* *}$ \\
\hline Control variable: homemaker & $0.01(0.09)$ & $0.01 \quad(0.24)$ & $0.01(0.06)$ \\
\hline Years of education & $0.06(8.21)^{* * *}$ & $0.06(8.05)^{* * *}$ & $0.06(7.76)^{* * *}$ \\
\hline \multicolumn{4}{|l|}{ Horizontal differentiation: } \\
\hline Age in years & $-0.04(-20.85)^{* * *}$ & $-0.04(-20.90)^{* * *}$ & $-0.04(-20.77)^{* * *}$ \\
\hline Gender $($ female $=1)$ & $-0.17(-5.58)^{* * *}$ & $-0.17(-5.75)^{* * *}$ & $-0.17(-5.72)^{* * *}$ \\
\hline Nationality (German=1) & $-0.21(-2.38)^{*}$ & $-0.22(-2.41)^{*}$ & $-0.22(-2.44)^{*}$ \\
\hline \multicolumn{4}{|l|}{ Health behaviour: } \\
\hline Regular tobacco consumption & $-0.25(-8.03)^{* * *}$ & $-0.25(-7.97)^{* * *}$ & $-0.25(-7.99)^{* * *}$ \\
\hline Regular alcohol consumption & $0.09(1.67)^{+}$ & $0.08 \quad(1.59)$ & $0.08 \quad(1.49)$ \\
\hline Body-mass index (metric) & $-0.06(-16.21)^{* * *}$ & $-0.06(-16.34)^{* * *}$ & $-0.06(-16.34)^{* * *}$ \\
\hline \multicolumn{4}{|l|}{ Resources: } \\
\hline Marital status ( $1=$ married $)$ & $-0.04(-0.95)$ & $-0.03(-0.85)$ & $-0.03(-0.85)$ \\
\hline Has a confidant & $0.07 \quad(1.23)$ & $0.07(1.25)$ & $0.07(1.20)$ \\
\hline Square metres per person (In) & $0.01 \quad(0.29)$ & $0.02 \quad(0.41)$ & $0.01 \quad(0.32)$ \\
\hline \multicolumn{4}{|l|}{ Stress: } \\
\hline Job at risk & $-0.38(-8.80)^{* * *}$ & $-0.38(-8.82)^{* * *}$ & $-0.38(-8.88)^{* * *}$ \\
\hline More than 5 overtime hours & $-0.10(-2.47)^{*}$ & $-0.10(-2.58)^{*}$ & $-0.11(-2.62)^{*}$ \\
\hline Dissatisfied: dwelling & $-0.54(-10.65)^{* * *}$ & $-0.54(-10.54)^{* * *}$ & $-0.54(-10.49)^{* * *}$ \\
\hline Dissatisfied: family & $-0.74(-14.81)^{* * *}$ & $-0.73(-14.78)^{* * *}$ & $-0.73(-14.70)^{* * *}$ \\
\hline \multicolumn{4}{|l|}{ Level 2 (ROR): } \\
\hline Gini index income & $0.02 \quad(1.18)$ & $0.01 \quad(0.55)$ & $0.01 \quad(0.58)$ \\
\hline Avg. household income in $1000 €$ & & $0.26 \quad(1.32)$ & $0.26 \quad(1.27)$ \\
\hline Gini index years of education & $-0.03(-0.80)$ & $-0.02(-0.43)$ & $-0.01(-0.18)$ \\
\hline Avg. years of education & & $0.05 \quad(0.64)$ & $0.03 \quad(0.39)$ \\
\hline Unemployment rate & & $1.53(1.59)$ & $1.75(1.80)^{+}$ \\
\hline \multicolumn{4}{|l|}{ Cross-level effects: } \\
\hline Gini income ${ }^{*}$ income & & & $0.00 \quad(0.12)$ \\
\hline Avg. household income * income & & & $-0.02(-0.65)$ \\
\hline Gini years of education ${ }^{*}$ years of education & & & $0.02(3.24)^{* *}$ \\
\hline Avg. years of education * years of education & & & $-0.03(-1.55)$ \\
\hline Unemployment rate ${ }^{*}$ unemployed & & & $-1.03(-1.32)$ \\
\hline Number of cases (level 1) & 15,036 & 15,036 & 15,036 \\
\hline Number of cases (level 2) & 97 & 97 & 97 \\
\hline
\end{tabular}

$+\mathrm{p}<0.10,{ }^{*} \mathrm{p}<0.05,{ }^{* *} \mathrm{p}<0.01,{ }^{* * *} \mathrm{p}<0.001$, authors' calculations, controlled for degree of urbanisation at level 1

Note: Unless noted otherwise 1 means yes and 0 stands for no.

Source: SOEP 2006 (Level 1), pooled ROR Microcensus 2005 (Level 2) 
health. Health resources remain without effect. Confidants and a spacious living environment, measured in the number of square metres per person, have no healthpromoting influence. The stress factors (fear of losing a job, overtime hours, dissatisfaction with own dwelling and family) all have negative effects on health chances. Unemployment is accompanied by a decrease in health chances, while the status of homemaker does not vary with individual health.

The contextual variables encompass income and educational inequality, income and educational level as well as the unemployment rate at the ROR level. The income level and income inequality are not significant with very low t-values (refuting hypotheses $1 a$ and $4 a$ ). Regional educational inequality and the regional educational level also have no effects on individual health (refuting hypotheses $2 a$ and $5 a$ ). Local unemployment has only a very weak influence on individual health, which is only significant in the model with cross-level effects (Model C) at the 10 percent level, whereby we note that a tendency to the opposite effect of Hypothesis $3 a$ is proven. Finally, the above-mentioned cross-level effects from Model $\mathrm{C}$ are particularly interesting. While the interaction between income inequality and individual income, income level and individual income, educational level and individual education as well as the interaction between local unemployment and individual unemployment each have no significant effect (contrary to hypotheses $4 b, 1 b, 2 b$ and $3 b$ ), the interaction term of educational inequality and the individual level of education exhibits a highly significant effect (preliminarily confirming Hypothesis $5 b$ ). People with high levels of education profit from an educationally disparate regional environment, or, respectively, in addition to their individual health disadvantage people with low levels of education exhibit even additional lesser health chances in an educationally disparate environment.

Nonetheless, men and women are not equally affected by regional influences. For this reason, additional separate models were calculated, which are presented in Table 5. The control variables at the individual level were not portrayed in this table since hardly any surprising results can be reported. Only one effect on the individual level is worth mentioning here: Overtime hours are negatively associated with women's health, while there is no significant difference among men.

Controlled for the individual variables (from Table 4), the influences of regional income and educational inequality as well as regional unemployment have neither an effect on women's nor on men's health (cf. Table 5). The effect of the average years of education in a region is only significant among men when not controlled for the income level (compare Models F and G for men). Among women the crosslevel effect is of particular significance here. In this case, high educational inequality intensifies the individual educational effect (corresponding to Hypothesis $5 b$ ). This means that highly educated women profit most in educationally disparate regions, while women from less-educated groups experience an additional regional health disadvantage alongside their individual disadvantage (cf. models $D$ and $E$ ). This effect is only significant at the 10 percent level among men. If we regard the income level combined with individual income among men, a high regional income level weakens the individual income effect for men. When the regional income level is high, it seems as if individual income has a lesser effect. Among men the unem- 
Tab. 5: Random effects logit models broken down by gender (dependent variable: subjective health: $1=$ very good/good, age $25-65$ years, population-average models, robust standard errors, controlled for level 1 variables)

\begin{tabular}{|c|c|c|c|c|}
\hline & \multicolumn{4}{|c|}{ Coefficient (t-value) } \\
\hline & $\begin{array}{l}\text { Model D } \\
\text { Women }\end{array}$ & $\begin{array}{l}\text { Model E } \\
\text { Women }\end{array}$ & $\begin{array}{l}\text { Model F } \\
\text { Men }\end{array}$ & $\begin{array}{l}\text { Model G } \\
\text { Men }\end{array}$ \\
\hline Constant & $0.07(2.49)^{*}$ & $0.07(2.49)^{*}$ & $0.17(5.07)^{* * *}$ & $0.17(5.07)^{* * *}$ \\
\hline \multicolumn{5}{|l|}{ Level 2 (ROR): } \\
\hline Gini index income & 0.03 (1.59) & & $0.01(0.11)$ & \\
\hline Avg. household income in $1000 €$ & & $-0.07(-0.32)$ & & $0.36(1.28)$ \\
\hline Gini index years of education & $-0.01(-0.30)$ & $0.02(0.43)$ & $-0.01(-0.35)$ & $-0.02(-0.44)$ \\
\hline Avg. years of education & $-0.05(-0.58)$ & $0.01(0.07)$ & $0.21(2.10)^{*}$ & $0.16(1.43)$ \\
\hline Unemployment rate & $0.95(1.52)$ & $0.27(0.25)$ & $-0.17(-0.22)$ & $1.51(1.04)$ \\
\hline \multicolumn{5}{|l|}{ Cross-level effects: } \\
\hline Gini income*income & $-0.00(-0.36)$ & & $-0.00(-0.25)$ & \\
\hline Avg. household income*income & & $-0.01(-0.34)$ & & $-0.05(-2.14)^{*}$ \\
\hline $\begin{array}{l}\text { Gini years of education*years of } \\
\text { education }\end{array}$ & $0.02(2.13)^{*}$ & $0.02(2.15)^{*}$ & $0.02(1.84)^{+}$ & $0.02(1.89)^{+}$ \\
\hline $\begin{array}{l}\text { Avg. years of education*years of } \\
\text { education }\end{array}$ & $-0.02(-0.70)$ & $-0.02(-0.66)$ & $-0.04(-1.64)$ & $-0.04(-1.66)^{+}$ \\
\hline unemployment rate ${ }^{*}$ unemployed & $-0.55(-0.62)$ & $-0.41(-0.37)$ & $-2.10(-2.51)^{*}$ & $-1.02(-1.18)$ \\
\hline $\mathrm{N}_{1} / \mathrm{N}_{2}$ & $7811 / 97$ & $7811 / 97$ & $7225 / 97$ & 7225 / 97 \\
\hline
\end{tabular}

$+p<0.10,{ }^{*} p<0.05,{ }^{* *} p<0.01,{ }^{* * *} p<0.001$, authors' calculations

Source: 2006 SOEP (level 1), pooled ROR 2005 Microcensus (level 2). The results were controlled for the individual variables (cf. Table 4) but are not portrayed in Table 5 .

ployment rate also has a different impact than among women. High regional unemployment intensifies the negative individual effect of unemployment. Presumably, the frustration of unemployed men in regions with a high unemployment rate is particularly great because the chances for a new job are especially low there, which, in turn, has a particularly health-damaging effect (the assumption of Hypothesis $3 \mathrm{~b}$ only applies to men).

\section{$5 \quad$ Summary and discussion}

The purpose of this article is to explain individual health chances with regionally varying inequality dimensions. Controlled for relevant individual variables, the regional influence of income and educational level, income and educational inequality as well as the local unemployment rate are ascribed an independent effect on individual health. This appears quite reasonable since in many existing studies smallarea effects also remain significant when controlled for the main individual determinants. Unlike similar Anglo-American studies, however, this article makes use of relatively large regional units (Raumordnungsregionen) to delimit the contextual 
effects. This has the advantage that the single parameters for regional inequality are based on a solid data basis since the complete number of cases from the $2005 \mathrm{Mi}$ crocensus (almost 700,000 cases) are used to describe the RORs. The disadvantage of this method is that due to their size, the regions exhibit considerable heterogeneity with regard to the relevant inequality dimensions. For this reason, small-area regional effects tended to be underestimated in this article, i.e. very conservative results are presented at the second level of analysis.

The individual effects on health chances presented here are a good replication of current research. It becomes interesting, however, when regional contextual effects are taken into account. The respective main effects are by and large not significant, i.e. neither income level, educational and income inequality nor regional unemployment influence individual health chances. Solely the regional educational level has a slightly positive effect on the health of men; this result is, however, not very robust. The interaction between regional educational inequality and individual education, though, exhibits a highly significant positive effect: Increasing educational inequality in a region intensifies the individual educational effect. Less-educated groups then have even lesser and highly educated people even better health chances. Broken down by gender, this effect is specifically dominant among women. Regarding unemployment, the picture is different. Men suffer from their individual unemployment more severely when unemployment in the region is high; there is no such effect among women. This result indicates two conclusions: 1) compared with women, the wellbeing of men is still far more dependent upon whether they can fulfil the role of "breadwinner" and participate in the labour market and 2) chances of returning to the labour market based on the regional unemployment rate appear to be anticipated and poor career prospects in the region seem to have an additional negative effect on men's health. Since we only work with cross-sectional data we cannot, however, exclude the opposite causation whereby ill men in structurally weak regions find it particularly difficult to enter the labour market.

In their study Galea and Ahern (2005) interpret the educational level effect as all people in regions with high educational levels profit from the health-promoting effect of the highly educated: "The presence in a neighborhood of highly educated people may be salutary for all residents, independent of the potentially deleterious consequences of income maldistribution" (Galea/Ahern 2005: 2198). Galea and Ahern (2005), however, did not look at any cross-level effects, which, in our opinion, may be the reason that their relevant conclusions come up short. The cross-level effect of regional educational inequality on the effect of individual years of education presented by us illustrates that regional educational inequality intensifies the individual educational effect.

The interpretation of this effect is by no means trivial and should be only done as part of careful speculation. Since a low level of education is associated with poorer health of the population, a noticeably high incidence of poor health behaviour, health problems and diseases could lead to an increased implementation of preventive measures in educationally disparate areas. We know of these types of measures, however, that they often remain ineffective among those people who need the assistance most urgently. For example, after completing a measure for the prevention 
of obesity, obese children of highly educated parents quickly attain a significantly improved body weight, while children of less-educated groups do not profit from the same measures (Plachta-Danielzik et al. 2008). This type of mechanism could lead to the health of highly educated people profiting in particular in educationally disparate areas. Previous studies usually focus on income and prosperity indicators and largely neglect the importance of educational level and inequality of regions. Future research should take this more into consideration.

\section{Acknowledgements}

We would like to thank Tim Hochgürtel from the Research Data Centre of the German Federal Statistical Office for conducting the controlled remote data processing and Dominika Urbanski for her support concerning the literature review. We also thank the participants of the Rational Choice Sociology Conference (Venice International University) as well as the anonymous reviewers and the editors for their helpful remarks.

\section{References}

Albrecht, Gary L.; Fitzpatrick, Ray; Scrimshaw, Susan C. (Eds.) 2001: Handbook of Social Studies in Health and Medicine. London: Sage [doi: 10.4135/9781848608412].

Allison, Paul D. 1978: Measures of Inequality. In: American Sociological Review 43: 865-880.

Altenhofen, Lutz 1998: Das Programm zur Krankheits-Früherkennung bei Kindern. Inanspruchnahme und Datenlage. In: Bundeszentrale für gesundheitliche Aufklärung (Eds.): Gesundheit von Kindern. Epidemiologische Grundlagen. Forschung und Praxis in der Gesundheitsförderung 3. Köln: BZgA: 24-33.

Babones, Salvatore J. 2008: Income inequality and population health: Correlation and causality. In: Social Science \& Medicine 66,7: 1614-1626 [doi: 10.1016/j. socscimed.2007.12.012].

Backlund, Eric; Sorlie, Paul D.; Johnson, Norman J. 1996: The shape of the relationship between income and mortality in the United States: Evidence from the National Longitudinal Mortality Study. In: Annals of Epidemiology 6,1: 12-20 [doi: 10.1093/ije/ dym012].

Backlund, Eric et al. 2007: Income inequality and mortality: a multilevel prospective study of 521248 individuals in 50 US states. In: International Journal of Epidemiology 36: 590-596 [doi: 10.1093/ije/dym012].

Bauer, Ullrich; Bittlingmayer, Uwe H.; Richter, Matthias (Eds.) 2008: Health Inequalities: Determinanten und Mechanismen gesundheitlicher Ungleichheit. Wiesbaden: VS Verlag.

Beckfield, Jason 2004: Does Income Inequality Harm Health? New Cross-National Evidence. In: Journal of Health and Social Behavior 45,3: 231-248 [doi: 10.1177/002214650404500301].

Bird, Chloe E.; Conrad, Peter; Fremont, Allen M. (Eds.) 2000: Handbook of Medical Sociology. 5. Aufl. Upper Saddle River: Prentice Hall. 
Blane, David; Bartley, Mel; Smith, George Davey 1997: Disease aetiology and materialist explanations of socioeconomic mortality differentials. In: European Journal of Public Health 7,4: 385-391 [doi: 10.1093/eurpub/7.4.385].

Borrell, Luisa N. et al. 2004: Neighbourhood characteristics and mortality in the Atherosclerosis Risk in Communities Study. In: International Journal of Epidemiology 33,2: 398-407 [doi: 10.1093/ije/dyh063].

Bosma, Hans et al. 2001: Neighborhood Socioeconomic Status and All-Cause Mortality. In: American Journal of Epidemiology 153,4: 363-371 [doi: 10.1093/aje/153.4 .363].

Bundesinstitut für Bau-, Stadt- und Raumforschung im Bundesamt für Bauwesen und Raumordnung (BBR) 2009: Laufende Raumbeobachtung - Raumabgrenzungen. In: http://www.bbsr.bund.de/nn_1067638/BBSR/DE/Raumbeobachtung/Raumabgrenzungen/Raumordnungsregionen/raumordnungsregionen_node.html? _nnn=true, 03.06.13.

Bundeszentrale für gesundheitliche Aufklärung (Eds.) 1998: Gesundheit von Kindern. Epidemiologische Grundlagen. Forschung und Praxis in der Gesundheitsförderung 3. Köln: BZgA.

Case, Anne; Paxson, Christina 2005: Sex Differences in Morbidity and Mortality. In: Demography 42,2: 189-214 [doi: 10.1353/dem.2005.0011].

Cockerham, William C. 1999: Health and social change in Russia and Eastern Europe. London: Routledge [doi: 10.1177/002214650504600105].

Cockerham, William C. et al. 2005: Health lifestyles in Ukraine. In: Sozial- und Präventivmedizin 50,4: 51-67.

Cubbin, Catherine; LeClere, Felicia B.; Smith, George S. 2000: Socioeconomic status and injury mortality: individual and neighbourhood determinants. In: Journal of Epidemiology and Community Health 54: 517-524 [doi:10.1136/jech.54.7.517].

Cummins, Steven; Curtis, Sarah; Diez-Roux, Ana V.; Macintyre, Sally 2007: Understanding and presenting "place" in health research: A relational approach. In: Social Science \& Medecine 65: 1825-1838 [doi:10.1016/j.socscimed.2007.05.036].

Dahl, Espen et al. 2006: Welfare state regimes and health inequalities. 9. In: Siegrist, Johannes; Marmot, Michael (Eds.): Social inequalities in health: new evidence and policy implications. Oxford: University Press: 193-222.

Diez-Roux, Ana V. 2001: Investigating neighborhood and area effects on health. In: American Journal of Public Health 91,11: 1783-1789 [doi: 10.2105/AJPH.91.11.1783].

Ecob, Russell; Smith, George D. 1999: Income and health: what is the nature of the relationship? In: Social Science \& Medicine 48,5: 693-705.

Engström, Karin et al. 2008: Contextual social capital as a risk factor for poor self-rated health: A multilevel analysis. In: Social Science \& Medicine 66,11: 2268-2280 [doi: 10.1016/j.socscimed.2008.01.019].

Franzini, Luisa; Ribble, John; Spears, William 2001: The Effects of Income Inequality and Income Level on Mortality Vary by Population Size in Texas Counties. In: Journal of Health and Social Behavior 42,4: 373-383.

Galea, Sandro; Ahern, Jennifer 2005: Distribution of Education and Population Health: An Ecological Analysis of New York City Neighborhoods. In: American Journal of Public Health 95,12: 2198-2205 vom 19.11.2009 [doi: 10.2105/AJPH.2004.050617].

Gerdtham, Ulf-G; Johannesson, Magnus 2004: Absolute Income, Relative Income, Income Inequality, and Mortality. In: The Journal of Human Resources 39,1: 228-247. 
Gerhards, Jürgen; Rössel, Jörg 2003: Das Ernährungsverhalten Jugendlicher im Kontext ihrer Lebensstile. Eine empirische Studie. Forschung und Praxis der Gesundheitsförderung 20. Köln: Bundeszentrale für gesundheitliche Aufklärung (BZgA [doi: 10.3239/9783640083756]).

Gini, Corrado 1921: Measurement of Inequality of Incomes. In: The Economic Journal 31: 124-126.

Gravelle, Hugh 1998: How much of the relation between population mortality and unequal distribution of income is a statistical artefact? In: British Medical Journal 316: 382-385.

Greiner, Birgit A. 2001: Psychosoziale Belastungen und Ressourcen am Arbeitsplatz. In: Mielck, Andreas; Bloomfield, Kim (Eds.): Sozial-Epidemiologie. Eine Einführung in die Grundlagen, Ergebnisse und Umsetzungsmöglichkeiten. Weinheim: Juventa: 141-156.

Gross, Christiane; Groß, Jochen 2008: Rational-Choice-Erklärungen zum Rauchverhalten und ihre empirische Relevanz. In: Soziale Welt 59,3: 247-268.

Haan, Mary; Kaplan, George A.; Camacho, Terry 1987: Poverty and Health: Prospective Evidence from the Alameda County Study. In: American Journal of Epidemiology 125,6: 989-998.

Heidrich, Jan et al. 2002: Self-Rated Health and its Relation to All-Cause and Cardiovascular Mortality in Southern Germany. Results from the MONICA Augsburg Cohort Study 1984-1995. In: Annals of Epidemiology 12,5: 338-345 [doi: 10.1016/ s1047-2797(01)00300-3].

Helmert, Uwe 2003: Soziale Ungleichheit und Krankheitsrisiken. Augsburg: Maro.

Helmert, Uwe; Mielck, Andreas; Shea, Stephen 1997: Poverty, health, and nutrition in Germany. In: Reviews on Environmental Health 12,3: 159-170.

Helmert, Uwe; Schorb, Friedrich 2009: Die Bedeutung verhaltensbezogener Faktoren im Kontext der sozialen Ungleichheit der Gesundheit. In: Richter, Matthias; Hurrelmann, Klaus (Eds.): Gesundheitliche Ungleichheit. Grundlagen, Probleme, Perspektiven. Wiesbaden: VS Verlag: 133-148 [doi: 10.1007/978-3-531-91643-9].

Holt-Lunstad, Julianne; Smith, Timothy B.; Layton, J. Bradley 2010: Social Relationships and Mortality Risk: A Meta-analytic Review. In: PLoS Medicine 7,7: 1-20 [doi: 10.1371/ journal.pmed.1000316].

Hox, Joop 2002: Multilevel analysis. Techniques and applications. Mahwah, NJ: Erlbaum.

Hurrelmann, Klaus; Klocke, Andreas; Metzer, Wolfgang (Eds.) 2003: Jugendgesundheitssurvey. Internationale Vergleichsstudie im Auftrag der Weltgesundheitsorganisation WHO. Weinheim: Juventa.

Idler, Ellen L.; Benyamini, Yae/ 1997: Self-Rated Health and Mortality. A Review of Twenty-Seven Community Studies. In: Journal of Health and Social Behavior 38: 21-37.

Janßen, Christian et al. 2009: Der Einfluss sozialer Ungleichheit auf die medizinische und gesundheitsbezogene Versorgung in Deutschland. In: Richter, Matthias; Hurrelmann, Klaus (Eds.): Gesundheitliche Ungleichheit. Grundlagen, Probleme, Perspektiven. Wiesbaden: VS Verlag: 149-165 [doi: 10.1007/978-3-531-91643-9_8].

Jungbauer-Gans, Monika 2002: Ungleichheit, soziale Beziehungen und Gesundheit. Wiesbaden: Westdeutscher Verlag [doi: 10.1007/978-3-663-11690-5]. 
Jungbauer-Gans, Monika; Gross, Christiane 2009: Erklärungsansätze sozial differenzierter Gesundheitschancen. In: Richter, Matthias; Hurrelmann, Klaus (Eds.): Gesundheitliche Ungleichheit. Grundlagen, Probleme, Perspektiven. Wiesbaden: VS Verlag: 77-98 [doi: 10.1007/978-3-531-91643-9 4].

Kamphuis, Carlijn B.M. et al. 2007: Perceived environmental determinants of physical activity and fruit and vegetable consumption among high and low socioeconomic groups in the Netherlands. In: Health \& Place 13: 493-503 [doi: 10.1016/j. healthplace.2006.05.008].

Kawachi, Ichiro et al. 1997: Social capital, income inequality, and mortality. In: American Journal of Public Health 87,9: 1491-1498.

Kecskes, Robert; Wagner, Michael; Wolf, Christof (Eds.) 2004: Angewandte Soziologie. Wiesbaden: VS Verlag [doi: 10.1007/978-3-322-91384-5].

Kemptner, Daniela et al. 2008: Regionale Unterschiede des Gesundheitsverhaltens in Bayern - Mehrebenenanalyse einer bevölkerungsrepräsentativen Befragung in Verbindung mit sozioökonomischen Strukturdaten. In: Das Gesundheitswesen 70: 28-37 [doi: 10.1055/s-2007-1022523].

Klein, Thomas; Schneider, Sven; Löwel, Hannelore 2001: Bildung und Mortalität. Die Bedeutung gesundheitsrelevanter Aspekte des Lebensstils. In: Zeitschrift für Soziologie 30,5: 384-400.

Kondo, Naoki et al. 2009: Income inequality, mortality, and self rated health: meta-analysis of multilevel studies. In: BMJ 339: 1-9 [doi: 10.1136/bmj.b4471].

Krieger, Nancy 2001: Letters to the Editor. Historical roots of social epidemiology: socioeconomics gradients in health and contextual analysis. In: International Journal of Epidemiology 30: 899-903 [doi: 10.1093/ije/30.4.899].

Kriwy, Peter; Mielck, Andreas 2006: Versicherte der gesetzlichen Krankenversicherung (GKV) und der privaten Krankenversicherung (PKV): Unterschiede in Morbidität und Gesundheitsverhalten. In: Das Gesundheitswesen 68,5: 281-288 [doi: 10.1055/s-2006-926779].

Lampert, Thomas; Thamm, Michael 2007: Tabak-, Alkohol- und Drogenkonsum von Jugendlichen in Deutschland. Ergebnisse des Kinder- und Jugendgesundheitssurveys (KiGGS). In: Bundesgesundheitsblatt - Gesundheitsforschung - Gesundheitsschutz 50,5-6: 600-608 [doi: 10.1007/s00103-007-0221-y].

Lampert, Thomas; Thamm, Michael 2004: Soziale Ungleichheit des Rauchverhaltens in Deutschland. In: Bundesgesundheitsblatt - Gesundheitsforschung - Gesundheitsschutz 47,11: 1033-1042 [doi: 10.1007/s00103-004-0934-0].

Lane, Sandra D.; Cibula, Donald A. 2001: Gender and Health. In: Albrecht, Gary L.; Fitzpatrick, Ray; Scrimshaw, Susan C. (Eds.): Handbook of Social Studies in Health and Medicine. London: Sage: 136-153 [doi: 10.4135/9781848608412].

Larsen, Klaus; Merlo, Juan 2005: Appropriate Assessment of Neighborhood Effects on Individual Health: Integrating Random and Fixed Effects in Multilevel Logistic Regression. In: American Journal of Epidemiology 161,1: 81-88 vom 19.11.2009 [doi: 10.1093/ aje/kwi017].

Lee, Rebecca E.; Cubbin, Catherine; Winkleby, Marilyn 2007: Contribution of neighbourhood socioeconomic status and physical activity resources to physical activity among women. In: Journal of Epidemiology and Community Health 61: 882-890 [doi:10.1136/ jech.2006.054098].

Link, Bruce G.; Phelan, Jo C. 2000: Evaluating the Fundamental Cause Explanation for Social Disparities in Health. In: Bird, Chloe E.; Conrad, Peter; Fremont, Allen M. (Eds.): Handbook of Medical Sociology. Upper Saddle River: Prentice Hall: 33-45. 
Lochner, KimberlyA. etal. 2003: Social capital and neighborhood mortality rates in Chicago. In: Social Science \& Medicine 56,8: 1797-1805 [doi: 10.1016/S0277-9536(02)00177-6].

Lynch, John W. et al. 2000: Income inequality and mortality: importance to health of individual income, psychosocial environment, or material conditions. In: British Medical Journal 320: 1200-1204 [doi: 10.1136/bmj.320.7243.1200].

Lyyra, Tiina-Mari et al. 2009: Self-rated health and mortality in older men and women: A time-dependent covariate analysis. In: Archives of Gerontology and Geriatrics 48,1: 14-18 [doi: 10.1016/j.archger.2007.09.004].

Macinryre, Sally; Ellaway, Anne; Cummins, Steven 2002: Place effects on health: how can we conceptualise, operationalise and measure them? In: Social Science \& Medecine 55: 125-139 [doi: 10.1016/S0277-9536(01)00214-3].

Marinacci, Chiara et al. 2004: The role of individual and contextual socioeconomic circumstances on mortality. Analysis of time variations in a city of north west Italy. In: Journal of Epidemiology and Community Health 58: 199-207 [doi: 10.1136/ jech.2003.014928].

Martikainen, Pekka; Kauppinen, Tiina M.; Valkonen, Tapani 2003: Effects of the characteristics of neighbourhoods and the characteristics of people on cause specific mortality. A register based follow up study of 252,000 men. In: Journal of Epidemiology Community Health 57,3: 210-217 [doi: 10.1136/jech.57.3.210].

McLeod, Jane D.; Nonnemaker, James M.; Call, Kathleen T. 2004: Income Inequality, Race, and Child Well-being: An Aggregate Analysis in the 50 United States. In: Journal of Health and Social Behavior 45,3: 249-264 [doi: 10.1177/002214650404500302].

Mellor, Jennifer M.; Milyo, Jeffrey 2002: Income Inequality and Health Status in the United States: Evidence from Current Population Survey. In: The Journal of Human Resources XXXVII,3: 510-539 [doi: 10.2307/3069680].

Mie/ck, Andreas 2000: Soziale Ungleichheit und Gesundheit. Empirische Ergebnisse, Erklärungsansätze, Interventionsmöglichkeiten. Bern: Hans Huber.

Mie/ck, Andreas 2008: Regionale Unterschiede bei Gesundheit und gesundheitlicher Versorgung: Weiterentwicklung der theoretischen und methodischen Ansätze. In: Bauer, Ullrich; Bittlingmayer, Uwe H.; Richter, Matthias (Eds.): Health Inequalities: Determinanten und Mechanismen gesundheitlicher Ungleichheit. Wiesbaden: VS Verlag: 167-187.

Mielck, Andreas; Bloomfield, Kim (Eds.) 2001: Sozial-Epidemiologie. Eine Einführung in die Grundlagen, Ergebnisse und Umsetzungsmöglichkeiten. Weinheim: Juventa.

Mirowsky, John; Ross, Catherine E.; Reynolds, John 2000: Links Between Social Status and Health Status. In: Bird, Chloe E.; Conrad, Peter; Fremont, Allen M. (Eds.): Handbook of Medical Sociology. Upper Saddle River: Prentice Hall: 47-67.

Monden, Christiaan W.S.; van Lenthe, Frank J.; Mackenbach, Johan P. 2006: A simultaneous analysis of neighbourhood and childhood socio-economic environment with self-assessed health and health-related behaviours. In: Health \& Place 12: 394-403 [doi: 10.1016/j.healthplace.2005.03.003].

Moore, Spencer; Daniel, Mark; Kestens, Yan 2007: Is educational inequality protective? In: American Journal of Public Health 97,1: 8-9 [doi: 10.2105/AJPH.2006.101618].

Neuhaus, John M.; Kalbfleisch, John D.; Hauck, Walter W. 1991: A Comparison of ClusterSpecific and Population-Averaged Approaches for Analyzing Correlated Binary Data. In: International Statistical Review/Revue Internationale de Statistique 59,1: 25-35. 
Nuckolls, Katherine B.; Cassel, John; Kaplan, Berton H. 1972: Psychosocial assets, life crises and the prognosis of pregnancy. In: American Journal of Epidemiology 95,5: 431-441.

O’Campo, Patricia et al. 1997: Neighborhood Risk Factors for Low Birthweight in Baltimore: A Multilevel Analysis. In: American Journal of Public Health 87,7: 1113-1118 [doi: 10.2105/AJPH.87.7.1113].

Peter, Richard 2009: Psychosoziale Belastungen im Erwachsenenalter: Ein Ansatz zur Erklärung sozialer Ungleichverteilung von Gesundheit? In: Richter, Matthias; Hurre/mann, Klaus (Eds.): Gesundheitliche Ungleichheit. Grundlagen, Probleme, Perspektiven. Wiesbaden: VS Verlag: 117-131 [doi: 10.1007/978-3-531-91643-9_6].

Pickett, Kate E.; Pearl, Michelle 2001: Multilevel analyses of neighbourhood socioeconomic context and health outcomes: a critical review. In: Journal of Epidemiology and Community Health 55,2: 111-122 [doi: 10.1136/jech.55.2.111].

Plachta-Danielzik, Sandra; Kriwy, Peter; Müller, Manfred J. 2008: Die Schulintervention der Kieler Adipositaspräventionsstudie (KOPS). In: Prävention und Gesundheitsförderung 3: 206-212 [doi: 10.1007/s11553-008-0128-y].

Prahl, Hans-Werner; Setzwein, Monika 1999: Soziologie der Ernährung. Opladen: Leske + Budrich.

Pyatt, Graham 1976: On the Interpretation and Disaggregation of Gini Coefficients. In: The Economic Journal 86: 243-255.

Quinn, Brian C.; Catalano, Ralph A.; Felber, Eugene 2009: The Effect of CommunityLevel Unemployment on Preventive Oral Health Care Utilization. In: Health Services Research 44,1: 162-181 [doi: 10.1111/j.1475-6773.2008.00901.x].

Reijneveld, Sijmen A.; Verheij, Robert A.; Bakker, Dinny H. de 2000: The impact of area deprivation on differences in health: does the choice of the geographical classification matter? In: Journal of Epidemiology and Community Health 54: 306-313 [doi: 10.1136/ jech.54.4.306].

Richter, Matthias; Hurrelmann, Klaus (Eds.) 2009: Gesundheitliche Ungleichheit. Grundlagen, Probleme, Perspektiven. 2., aktualisierte Auflage. Wiesbaden: VS Verlag.

Richter, Matthias; Settertobulte, Wolfgang 2003: Gesundheits- und Freizeitverhalten von Jugendlichen. In: Hurrelmann, Klaus; Klocke, Andreas; Metzer, Wolfgang (Eds.): Jugendgesundheitssurvey. Internationale Vergleichsstudie im Auftrag der Weltgesundheitsorganisation WHO. Weinheim: Juventa: 99-157.

Rieker, Patricia P.; Bird, Chloe E. 2000: Sociological Explanations of Gender Differences in Mental and Physical Health. In: Bird, Chloe E.; Conrad, Peter; Fremont, Allen M. (Eds.): Handbook of Medical Sociology. Upper Saddle River: Prentice Hall: 98-113.

Robert, Stephanie A. et al. 2004: Socioeconomic Risk Factors for Breast Cancer: Distinguishing Individual- and Community-Level Effects. In: Epidemiology 15,4: 442-450 [doi: 10.1097/01.ede.0000129512.61698.03].

Robert, Stephanie A.; House, James S. 2001: Socioeconomic Inequalities in Health: Integrating Individual-, Community-, and Societal-Level Theory and Research. In: Albrecht, Gary L.; Fitzpatrick, Ray; Scrimshaw, Susan C. (Eds.): Handbook of Social Studies in Health and Medicine. London: Sage: 115-135.

Rothman, Kenneth J. 1986: Modern epidemiology. Boston: Little, Brown and Company.

Rugulies, Reiner; Siegrist, Johannes 2002: Soziologische Aspekte der Entstehung und des Verlaufs der koronaren Herzkrankheit. Soziale Ungleichverteilung der Erkrankung und chronische Distress-Erfahrungen im Erwerbsleben. Reihe Statuskonferenz Psychokardiologie 4. Frankfurt: VAS. 
Schnell, Rainer; Trappmann, Mark 2006: Konsequenzen der Panelmortalität im SOEP für Schätzungen der Lebenserwartung. In: Arbeitspapier Zentrum für Quantitative Methoden und Surveyforschung 2: 2-16.

Schunck, Reinhard; Windzio, Michael 2009: Ökonomische Selbstständigkeit von Migranten in Deutschland: Effekte der sozialen Einbettung in Nachbarschaft und Haushalt. In: Zeitschrift für Soziologie 38,2: 113-130.

Siegrist, Johannes 1996: Soziale Krisen und Gesundheit. Eine Theorie der Gesundheitsförderung am Beispiel von Herz-Kreislauf-Risiken im Erwerbsleben. Göttingen: Hogrefe.

Siegrist, Johannes; Theorell, Töres 2006: Socio-economic position and health. The role of work and employment. In: Siegrist, Johannes; Marmot, Michael (Eds.): Social inequalities in health: new evidence and policy implications. Oxford: University Press: 73-100 [doi: 10.1093/acprof:oso/9780198568162.003.0004].

Siegrist, Johannes; Marmot, Michael (Eds.) 2006: Social inequalities in health: new evidence and policy implications. Oxford: University Press.

Siegrist, Johannes et al. 2004: The Measurement of Effort-Reward Imbalance at Work: European Comparisons. In: Social Science \& Medicine 58: 1483-1499 [doi: 10.1016/ S0277-9536(03)00351-4]

Sloggett, Andrew; Joshi, Heather 1994: Higher mortality in deprived areas: community or personal disadvantage? In: British Medical Journal 309: 1470-1474 [doi: 10.1136/ bmj.309.6967.1470].

Smith, James P. 1999: Healthy Bodies and Thick Wallets: The Dual Relation Between Health and Economic Status. In: Journal of Economic Perspectives 13,2: 145-166 [doi: 10.1257/jep.13.2.145].

Stafford, Mai; Marmot, Michael 2003: Neighbourhood deprivation and health: does it affect us all equally? In: International Journal of Epidemiology 32,3: 357-366 [doi: 10.1093/ije/dyg084].

Stafford, Mai et al. 2004: Neighbourhoods and self rated health: a comparison of public sector employees in London and Helsinki. In: Journal of Epidemiology and Community Health 58,9: 772-778 [doi: 10.1136/jech.2003.015941].

Statistisches Bundesamt (Eds.) 1998: Gesundheitsbericht für Deutschland. Gesundheitsberichterstattung des Bundes. Stuttgart: Metzler-Poeschel.

Steinkamp, Günther 1993: Soziale Ungleichheit, Erkrankungsrisiko und Lebenserwartung. Kritik der sozialepidemiologischen Ungleichheitsforschung. In: Sozial- und Präventivmedizin 38,3: 111-122 [doi: 10.1007/BF01324344].

Steptoe, Andrew; Feldman, Pamela J. 2001: Neighborhood Problems as Sources of Chronic Stress: Development of a Measure of Neighborhood Problems, and Associations With Socioeconomic Status and Health. In: Annals of Behavioral Medicine 23,3: 177-185 [doi: 10.1207/S15324796ABM2303_5].

Subramanian, Subu; Kawachi, Ichiro 2004: Income Inequality and Health: What Have We Learned So Far? In: Epidemiologic Reviews 26: 78-91 [doi: 10.1093/epirev/mxh003].

Tampubolon, Gindo 2012: Neighbourhood Social Capital and Individual Mental Health. In: van Ham, Maarten; Manley, David; Bailey, Nick; Simpson, Ludi; Maclennen, Duncan (Eds.): Neighbourhood Effects Research: New Perspectives. U.a. Dordrecht: Springer: 175-193 [doi: 10.1007/978-94-007-2309-2_8]. 
van Lenthe, Frank J. 2006: Aggregate deprivation and effects on health. In: Siegrist, Johannes; Marmot, Michael (Eds.): Social inequalities in health: new evidence and policy implications. Oxford: University Press: 167-192 [doi: 10.1093/acprof:oso/9780 198568162.001.0001].

van Lenthe, Frank J. et al. 2005a: Neighbourhood unemployment and all cause mortality: a comparison of six countries. Journal of Epidemiology and Community Health 59: 231-237 [doi: 10.1136/jech.2004.022574].

van Lenthe, Frank J.; Brug, Johannes; Mackenbach, Johan P. 2005b: Neighbourhood inequalities in physical inactivity: the role of neighbourhood attractiveness, proximity to local facilities and safety in the Netherlands. In: Social Science \& Medicine 60: 763-775 [doi: 10.1016/j.socscimed.2004.06.013].

van Lenthe, Frank J.; Martikainen, Pekka; Mackenbach, Johan P. 2007: Neighbourhood inequalities in health and health-related behaviour: Results of selective migration? In: Health \& Place 13: 123-137 [doi: 10.1016/j.healthplace.2005.09.013].

Veugelers, Paul J.; Yip, Alexandra M.; Kephart, George 2001: Proximate and Contextual Socioeconomic Determinants of Mortality: Multilevel Approaches in a Setting with Universal Health Care Coverage. In: American Journal of Epidemiology 154,8: 725-732 [doi: 10.1093/aje/154.8.725].

Voigtländer, Sven; Berger, Ursula; Razum, Oliver 2010: The impact of regional and neighbourhood deprivation on physical health in Germany: a multilevel study. In: BMC Public Health 10,1: 403 [doi: 10.1186/1471-2458-10-403].

Voigtländer, Sven et al. 2011: Using geographically referenced data on environmental exposures for public health research: a feasibility study based on the German SocioEconomic Panel Study (SOEP). In: SOEPpapers on Multidisciplinary Panel Data Research: 1-20.

Wilkinson, Richard G. 1997: Commentary: Income inequality summarises the health burden of individual relative deprivation. In: British Medical Journal 314: 1727-1728 [doi: 10.1136/bmj.314.7096.1727].

Wilkinson, Richard G. 2001 [1996]: Kranke Gesellschaften. Soziales Gleichgewicht und Gesundheit. Wien, New York: Springer [doi: 10.1007/978-3-7091-6180-7].

Wilkinson, Richard G.; Pickett, Kate 2010: The Spirit Level. Why Equality is Better for Everyone. London: Penguin [doi: 10.1111/j.1468-2265.2012.00757_41.x].

Wolf, Christof 2004: Wohnquartiere und Gesundheit: Eine Mehrebenenanalyse. In: Kecskes, Robert; Wagner, Michael; Wolf, Christof (Eds.): Angewandte Soziologie. Wiesbaden: VS Verlag: 103-126 [doi: 10.1007/978-3-322-91384-5_5].

Yen, Irene H.; Kaplan, George A. 1999a: Poverty area residence and changes in depression and perceived health status: evidence from the Alameda County Study. In: International Journal of Epidemiology 28,1: 90-94 [doi: 10.1093/ije/28.1.90].

Yen, Irene H.; Kaplan, George A. 1999b: Neighborhood Social Environment and Risk of Death: Multilevel Evidence from the Alameda County Study. In: American Journal of Epidemiology 149,10: 898-907.

Zubrägel, Sabine; Settertobulte, Wolfgang 2003: Körpermasse und Ernährungsverhalten von Jugendlichen. In: Hurrelmann, Klaus; Klocke, Andreas; Metzer, Wolfgang (Eds.): Jugendgesundheitssurvey. Internationale Vergleichsstudie im Auftrag der Weltgesundheitsorganisation WHO. Weinheim: Juventa: 159-182. 
Translated from the original text by the Federal Institute for Population Research, for information only. The reviewed and authors' authorised original article in German is available under the title "Einfluss regionaler sozialer Ungleichheits- und Arbeitsmarktmerkmale auf die Gesundheit", DOI 10.4232/10.CPOS-2013-15de or URN urn:nbn:de:bib-cpos-2013-15de3, at http://www.comparativepopulationstudies.de.

Date of submission: 15.09 .2011

Date of Acceptance: 08.04.2013

Dr. Christiane Gross ( $\triangle$ ). Christian-Albrechts-Universität zu Kiel, Institut für Sozialwissenschaften, 24098 Kiel, Germany. E-Mail: cgross@soziologie.uni-kiel.de URL: http://www.soziologie.uni-kiel.de/mitarbeiter/gross/

Dr. Peter Kriwy. Friedrich-Alexander Universität Erlangen-Nürnberg, Lehrstuhl für Empirische Wirtschaftssoziologie, 90402 Nuernberg, Germany.

E-Mail: peter.kriwy@wiso.uni-erlangen.de

URL: http://www.sozialforschung.rw.uni-erlangen.de/lehrstuhlteam/mitarbeiterinnen/ peter-kriwy.shtml 


\section{Comparative Population Studies - Zeitschrift für Bevölkerungswissenschaft}

wWw.comparativepopulationstudies.de

ISSN: 1869-8980 (Print) - 1869-8999 (Internet)

Published by / Herausgegeben von

Prof. Dr. Norbert F. Schneider

Federal Institute for Population Research

D-65180 Wiesbaden / Germany

Managing Editor /

Verantwortlicher Redakteur

Frank Swiaczny

Assistant Managing Editor /

Stellvertretende Redakteurin

Katrin Schiefer

Language \& Copy Editor (English) /

Lektorat \& Übersetzungen (englisch)

Amelie Franke

Copy Editor (German) /

Lektorat (deutsch)

Dr. Evelyn Grünheid

\section{Layout / Satz}

Beatriz Feiler-Fuchs

E-mail: cpos@bib.bund.de

\author{
Scientific Advisory Board / \\ Wissenschaftlicher Beirat \\ Jürgen Dorbritz (Wiesbaden) \\ Paul Gans (Mannheim) \\ Johannes Huinink (Bremen) \\ Marc Luy (Wien) \\ Clara H. Mulder (Groningen) \\ Notburga Ott (Bochum) \\ Peter Preisendörfer (Mainz)
}

\section{Board of Reviewers / Gutachterbeirat} Martin Abraham (Erlangen)

Laura Bernardi (Lausanne) Hansjörg Bucher (Bonn) Claudia Diehl (Göttingen) Andreas Diekmann (Zürich) Gabriele Doblhammer-Reiter (Rostock) Henriette Engelhardt-Wölfler (Bamberg) E.-Jürgen Flöthmann (Bielefeld) Alexia Fürnkranz-Prskawetz (Wien) Beat Fux (Zürich) Joshua Goldstein (Rostock) Karsten Hank (Köln) Sonja Haug (Regensburg) Franz-Josef Kemper (Berlin) † Michaela Kreyenfeld (Rostock) Aart C. Liefbroer (Den Haag) Kurt Lüscher (Konstanz) Dimiter Philipov (Wien) Tomáš Sobotka (Wien) Heike Trappe (Rostock) 